\title{
PERBANDINGAN KEEFEKTIFAN PEMBELAJARAN PENDEKATAN METODE STUDENT CENTER LEARNING TIPE COOPERATIVE LEARNING DENGAN METODE CERAMAH TERHADAP HASIL BELAJAR MAHASISWA DIV KEPERAWATAN ANESTESIOLOGI ITS PKU MUHAMMADIYAH SURAKARTA
}

\author{
Ratih Prananingrum \\ DIV Keperawatan Anestesiologi, ITS PKU Muhammadiyah Surakarta \\ email : ratihprananingrum@gmail.com
}

\begin{abstract}
Abstrak
Pendahuluan: Salah satu komponen yang penting dalam pelajaran adalah metode mengajar, yang merupakan suatu cara untuk mencapai tujuan pengajaran. Metode mengajar adalah suatu pengetahuan tentang cara-cara mengajar dipergunakan oleh seorang guru atau instruktur. Cara memberdayakan peserta didik tidak hanya dengan menggunakan strategi atau metode ceramah saja, Salah satu metode yang terdapat pada student center learning adalah metode cooperative learning.
\end{abstract}

Tujuan: Tujuan penelitian untuk menganalisis perbandingkan antara keefektifan penerapan metode student center learning model cooperative learning dengan metode ceramah terhadap hasil belajar mata kuliah Komunikasi pada mahasiswa D IV Semester 2 di ITS PKU Muhammadiyah Surakarta.

Metode: Eksperimen dengan rancangan quasi eksperimen (Pre and Post test group). Subjek penelitian mahasiswa keperawatan anestesiologi Semester 2. Subjek berjumlah 62 responden.

Hasil: Rata-rata nilai pretest metode ceramah adalah sebesar 60,42 $( \pm 7,14)$ dan rata-rata nilai pretest metode cooperative learning sebesar $60,60( \pm 7,15)$ dan rata-rata nilai pretest metode ceramah 60,42 $( \pm 7,14)$ sedangkan rata-rata nilai posttest metode ceramah $96,28( \pm 3,89)$. Selisih rata-rata nilai posttest dan pretest 35,86 dan rata-rata nilai pretest metode cooperative learning adalah sebesar $60,60( \pm 7,15)$ sedangkan rata-rata nilai posttest metode cooperative learning $86,88( \pm 6,23)$. Selisih rata-rata nilai posttest dan pretest 26,28 dan rata-rata nilai posttest metode pembelajaran ceramah sebesar 96,28 $( \pm 3,89)$ dan rata-rata nilai posttest metode pembelajaran cooperative learning sebesar 86,88 $( \pm 6,23)$. Pada saat penerapan metode ceramah, dari 35 mahasiswa, kesemuanya aktif, terlihat dengan banyak mahasiswa yang bertanya tentang materi yang disampaikan, serta mampu menjawab pertanyaan yang diberikan oleh dosen ataupun pertanyaan yang berasal dari teman. Saat penerapan metode cooperative learning mahasiswa kurang aktif dalam kegiatan diskusi. mahasiswa kurang memahami perannya, serta kurang mampu untuk bertukar pendapat.

Kesimpulan: Dari hasil penelitian disimpulkan, terdapat keefektifan penerapan metode student center learning model cooperative learning dengan metode ceramah terhadap hasil belajar mata kuliah Komunikasi pada mahasiswa D IV Semester 2 di ITS PKU Muhammadiyah Surakarta.

Kata Kunci: Metode Student center learning, cooperative learning, metode ceramah, keefektifan

\footnotetext{
Abstract

Background: One important component in learning is the teaching method, which is a way to achieve teaching objectives. The teaching method is a knowledge of the teaching methods used by a teacher or instructor. How to empower students not only by using strategies or lecture methods, one method that is found in student center learning is the method of cooperative learning.

Purpose: The purpose of the study was to analyze the comparison between the effectiveness of the application of the cooperative learning model of student center learning models and the
} 
lecture method on the learning outcomes of Communication courses for students in D IV Semester 2 at ITS PKU Muhammadiyah Surakarta.

Methods: Experiment with a quasi-experimental design (Pre and Posttest group). The research subjects were Nursing Anesthesiology Semester 2. Subjects were 62 respondents.

Results: The average pretest value of the lecture method is $60.42( \pm 7.14)$ and the average value of the cooperative learning method pretest is $60.60( \pm 7.15)$ and the average pretest value of the lecture method is $60.42( \pm 7.14)$ while the average posttest value of lecture method is $96.28( \pm$ 3.89). The difference in the average value of posttest and pretest is 35.86 and the average value of the cooperative learning method pretest is $60.60( \pm 7.15)$ while the average value of the posttest cooperative learning method is $86.88( \pm 6.23)$. The difference between the average posttest and pretest scores was 26.28 and the average posttest value of the lecture learning method was $96.28( \pm 3.89)$ and the average posttest value of the cooperative learning method was $86.88( \pm 6.23)$. When applying the lecture method, out of 35 students, all of them were active, it was seen that there were many students who asked about the material presented, and were able to answer questions given by lecturers or questions from friends. When applying cooperative learning methods students are less active in discussion activities. students lack understanding of their role, and are less able to exchange opinions.

Conclusion: From the results of the study concluded, there is the effectiveness of the application of the method of student center learning model of cooperative learning with the lecture method on the learning outcomes of Communication courses for students of D IV Semester 2 at ITS PKU Muhammadiyah Surakarta.

Keywords: Student center learning method, cooperative learning, lecture method, effectiveness

\section{Pendahuluan}

Pendidikan Nasional adalah usaha secara sadar dan terencana untuk mewujudkan suasana belajar dan proses pembelajaran agar peserta didik secara aktif mengembangkan potensi dirinya untuk memiliki kekuatan spiritual, keagamaan, pengendalian diri, kebiasaan, kecerdasan, dan keterampilan yang diperlukan bagi dirinya, masyarakat, bangsa dan negara. Salah satu komponen yang penting dalam pembelajaran adalah metode mengajar, yang merupakan suatu cara untuk mencapai tujuan pengajaran. Seperti yang dikemukakan oleh Abu Ahmadi dan Tri prasetya (2015) bahwa: "Metode mengajar adalah suatu pengetahuan tentang cara-cara mengajar dipergunakan oleh seoraug guru atau instruktur".

Cara memberdayakan peserta didik tidak hanya dengan menggunakan strategi atau metode ceramah saja, sebagaimana yang selama ini banyak digunakan oleh para pendidik (dosen) dalam proses pembelajaran (Khoiriyah, 2010).

Salah satu metode yang terdapat pada student center learning adalah medel cooperative learning. Penerapan metode student center learning model cooperative learning diharapkan dapat menciptakan suasana belajar yang menyenangkan bagi mahasiswa dalam proses pembelajaran, sehingga mahasiswa tidak cepat bosan dengan materi yang diajarkan. Dengan demikian, diharapkan mahasiswa mampu mencapai hasil belajar yang optimal. (Utami, 2010). 
Hasil belajar pada hakikatnya adalah perubahan-perubahan tingkah laku yang mencakup aspek kognitif, afektif dan psikomotoris. Oleh sebab itu, dalam penilaian hasil belajar, peranan tujuan instruksional menjadi unsur penting sebagai dasar dan acuan penilaian (Sudjana, 2010).

Berdasarkan uraian di atas, maka penulis tertarik untuk mengadakan penelitian dengan judul "Perbandingan Keefektifan Pembelajaran Pendekatan Metode Student Center Learning model Cooperative Learning Dengan Metode Ceramah Terhadap Hasil Belajar Mahasiswa DIV Keperawatan Anestesiologi Semester 2 di ITS PKU Muhammadiyah Surakarta".

Istilah Student Center Learning (SCL) digunakan secara luas di dalam literatur yang membahas masalah-masalah pengajaran dan pendidikan. Istilah ini seringkali dikait- kaitkan dengan istilah-istilah lain seperti flexible learning, experiential learning, collaborative learning, constructivist learning, active learning, vicarious learning, cooperative learning dan self-directed learning. Oleh karena itulah, SCL seringkali didefinisikan dengan makna yang berbeda-beda pula (Kurhila, 2014).

Rogers (2013), SCL merupakan hasil dari transisis perpidahan kekuatan dalam proses pembelajaran, dari kekuatan dosen sebagai pakar menjadi kekuatan mahasiswa sebagai pembelajar. Perubahan ini terjadi setelah banyak harapan untuk memodifikasi.

Mendidik dengan ceramah berarti memberikan suatu informasi melalui pendengaran, yang hanya bisa dicerna otak mahasiswa 20\%. Padahal informasi yang dipelajari mahasiswa bisa saja dari membaca (10\%), melihat (30\%), melihat dan dengar (50\%), mengatakan (70\%), mengatakan dan melakukan (90\%) (Khoiriyah, 2010). Hal ini sesuai dengan pendapat seorang filosof Cina Konfusius bahwa "Apa yang saya dengar, saya lupa" "Apa yang saya lihat, saya ingat" "Apa yang saya lakukan, saya paham" (Silberman, 2011).

Strategi pembelajaran aktif sangat diperlukan karena peserta didik mempunyai cara belajar yang berbeda-beda. Hal ini disebut dengan gaya belajar atau learning style. Disamping itu, penggunaan strategi pembelajaran aktif bagi pendidik adalah sangat membantu atau memudahkan dalam mengajar. Bagi pendidik yang memiliki banyak jam mengajar, apabila dalam mengajar hanya berorientasi pada ceramah saja, maka jelas pendidik yang bersangkutan akan menghabiskan banyak energi karena mengeluarkan suara lisan melalui ceramah secara terus-menerus. Dilihat dari subjek didik maka metode student center learning merupakan proses kegiatan yang dilakukan mahasiswa dalam rangka belajar. Dilihat dari segi dosen/pengajar maka metode student center learning merupakan bagian strategi mengajar yang menuntut keaktifan optimal subjek didik (Khoiriyah, 2010). 
Tujuan utama dari penelitian ini adalah untuk membandingkan antara keefektifan penerapan metode student center learning model cooperative learning dengan metode ceramah terhadap hasil belajar mata kuliah Komunikasi Keperawatan Anestesiologi Semester 2 di ITS PKU Muhammadiyah Surakarta. Tujuan Khusus: untuk melihat hasil belajar mahasiswa DIV Keperawatan Anestesiologi terhadap mata kuliah psikologi dengan penerapan metode cooperative learning, Untuk melihat hasil belajar mahasiswa DIV Keperawatan Anestesiologi terhadap mata kuliah Komunikasi dengan penerapan metode ceramah.

\section{Metode Penelitian}

Desain penelitian ini menggunakan desain eksperimen semu (quasi eksperime) dilakukan di ITS PKU Muh Surakarta Prodi DIV Keperawatan Anestesiologi Semester 2 kelas A dan B pada bulan November sampai dengan Januari 2019. Pada penelitian ini, yang menjadi populasi adalah seluruh mahasiswa Keperawatan Anestesiologi Semester II ITS PKU Muh Surakarta yang berjumlah 62 orang (2 kelas). Teknik sampel adalah Kuota Sampling

Dari uji validitas dan reliabilitas didapatkan hasil sebagai berikut :

25 soal kuisioner, terdapat 22 soal valid, dan 3 soal tidak valid. Untuk nomer soal 3, 6, 14, tidak valid karena nilai $\mathrm{r}$ table $0.30>\mathrm{r}$ hitung, serta nilai $\mathrm{p}<0.05$. Hasil uji reliabilitas ditentukan sebagai berikut : bila nilai Alpha > 0,6 maka dinyatakan handal dan apabila nilai alpha < 0,6 maka instrument dinyatakan tidak handal (Nunally, 1969 dalam Ghozali, 2011).

\section{Hasil}

Tabel 1 Hasil Uji Perbedaan Pretest dan Posttest Kelompok Kontrol dan eksperimen

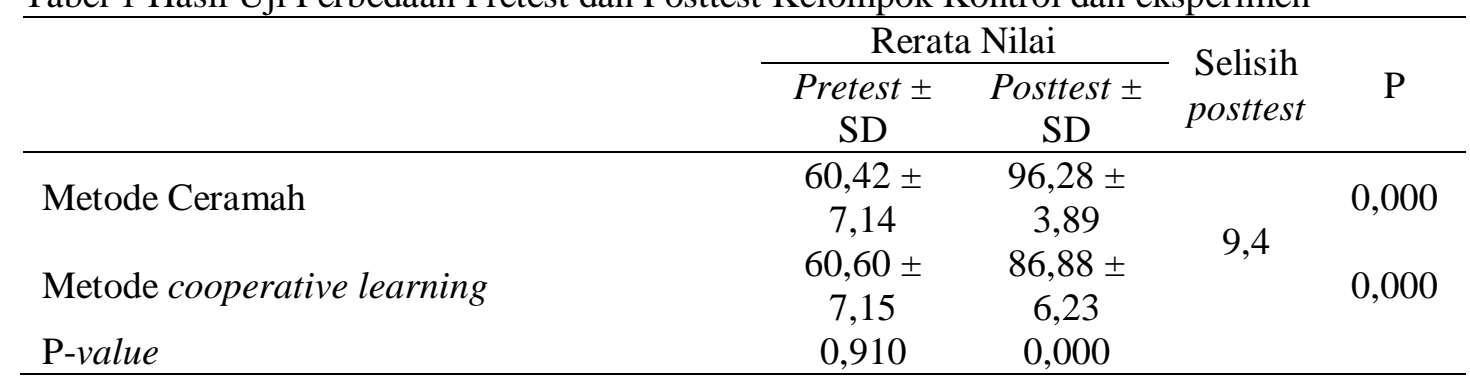

Sumber: Pengolahan Data Primer 2011

Tabel 4.1 memperlihatkan beberapa angka statistik deskriptif dan juga hasil pengujian selisih nilai pretest dan posttest kelompok kontrol dan kelompok eksperimen. Berdasarkan tabel 4.1 dapat dilakukan analisis sebagai berikut : 
Rata-rata nilai pretest metode ceramah adalah sebesar 60,42 dengan std. deviation \pm 7,14 dan rata-rata nilai pretest metode cooperative learning sebesar 60,60 dengan std. deviation $\pm 7,15$. Pengujian statistik menghasilkan signifikansi $\mathrm{p}$ sebesar $0,958>0,05$ menunjukkan bahwa selisih rata-rata pretest antara kedua kelompok tidak signifikan. Dengan demikian dapat disimpulkan bahwa tidak ada perbedaan yang bermakna pada kondisi awal kedua kelompok sebelum dilakukan pembelajaran baik dengan metode ceramah maupun metode cooperative learning.

Rata-ratanilai pretest metode ceramah adalah sebesar 60,42 dengan std. deviation \pm 7,14 sedangkan rata-rata nilai posttest metode ceramah adalah sebesar 96,28 dengan std. deviation $\pm 3,89$. Selisih rata-rata nilai posttest dan pretest adalah sebesar 35,86 . Pengujian statistik menghasilkan signifikansi p sebesar 0,000 $<0,05$ menunjukkan bahwa ada perbedaan yang bermakna sebelum dan sesudah menerima pembelajaran.

Rata-rata nilai pretest metode cooperative learning adalah sebesar 60,60 dengan std. deviation $\pm 7,15$ sedangkan rata-rata nilai posttest metode cooperative learning adalah sebesar 86,88 dengan std. deviation $\pm 6,23$. Selisih rata-rata nilai posttest dan pretest adalah sebesar 26,28. Pengujian statistik menghasilkan signifikansi p sebesar $0,000<0,05$ menunjukkan bahwa ada perbedaan yang bermakna sebelum dan sesudah pembelajaran.

Rata-rata nilai posttest metode pembelajaran ceramah sebesar 96,28 dengan std. deviation $\pm 3,89$ dan rata-rata nilai posttest metode pembelajaran cooperative learning sebesar 86,88 dengan std. deviation $\pm 6,23$. Dilihat dari nilai rata-rata antara kedua kelompok pembelajaran tersebut, kelompok pembelajaran dengan metode ceramah mempunyai nilai mean lebih besar daripada pembelajaran metode cooperative learning. Pengujian statistik menghasilkan signifikansi p sebesar $0,000<0,05$ hal ini menunjukkan ada perbedaan yang bermakna antara metode pembelajaran ceramah dengan metode cooperative learning.

\section{Pembahasan}


Hasil perhitungan statistik dari uji T-test, menunjukkan bahwa rata-rata nilai pretest dan posttest pada metode ceramah mengalami peningkatan, rata-rata nilai pretest dan posttest pada metode cooperative learning juga mengalami peningkatan, akan tetapi peningkatan yang terjadi pada kelompok pembelajaran dengan metode ceramah lebih besar daripada pembelajaran dengan metode cooperative learning (selisih posttest metode ceramah dan metode cooperative learning $=9,4)$. Jacobsen $(2017)$ prevalensi tentang ceramah sebagai metode pengajaran sebenarnya cukup paradoksal. Meskipun ceramah merupakan metode yang paling banyak dikritik dari seluruh metode pengajaran, namun justru terus menjadi metode yang paling sering digunakan.

Popularitas metode ceramah disebabkan karena metode ceramah mampu melakukan hal-hal berikut ini : Membantu mahasiswa memperoleh informasi yang tidak mudah diperoleh dengan cara-cara yang lain, ceramah bisa menjadi efektif jika tujuannya adalah untuk memberi mahasiswa informasi yang jika mahasiswa mencoba menemukannya sendiri, akan memakan waktu lama hingga berjam-jam lamanya, membantu mahasiswa dalam memadukan informasi dari sumber-sumber yang berbeda, dan menyingkapkan mahasiswa pada cara pandang yang berbeda. Pada dasarnya metode ini dapat digunakan pada semua jenis pembelajaran, terutama untuk pembelajaran membaca, dan atau yang memerlukan analisa mendalam, penyampaian informasi yang sulit mendapatkan bahan reverensi, metode ini sangat membantu (Syaiful Bahri Djamarah, 2015).

Metode cooperative learning merupakan metode pembelajaran yang memanfaatkan interaksi antara dosen dengan mahasiswa juga antara mahasiswa dengan mahasiswa dimana dalam penerapannya, terdiri dari kegiatan diskusi kelompok, diskusi antar kelompok, presentasi kelompok, dan kegiatan tanya jawab antar kelompok, sehingga dapat menarik perhatian dan keaktifan mahasiswa. Roy Killen (2016), Prinsip utama pola pembelajaran ini adalah "peer teaching" pembelajaran oleh teman sendiri, akan menjadi kendala karena perbedaan persepsi dalam memahami suatu konsep yang akan didiskusikan bersama dengan siswa lain, dirasa sulit meyakinkan siswa untuk mampu berdiskusi menyampaikan materi pada teman, jika siswa tidak memiliki rasa kepercayaan diri, rekod siswa tentang nilai, kepribadian, perhatian siswa harus sudah dimiliki oleh pendidik dan ini biasanya dibutuhkan waktu yang cukup lama untuk mengenali tipe-tipe siswa dalam kelompok tersebut. Teknik ini menggabungkan antara menulis, mendengarkan dan berbicara. Akan tetapi, bahan pengajaran yang paling cocok digunakan dalam metode ini adalah bahan yang membutuhkan pertukaran pengalaman, pikiran, dan informasi antar siswa (Aronson,Lie, 2014). 
Bagi mahasiswa yang tidak terbiasa belajar kelompok, mereka akan merasa asing dan tidak terbiasa, memerlukan lebih banyak waktu, tenaga, dan fikiran untuk melakukan metode ini, sebaiknya pelaksanaan pembelajaran dengan menggunakan metode cooperative tidak digunakan untuk pembelajaran setiap harinya (Mabroer, 2016).

\section{Kesimpulan}

Rata-rata nilai posttest metode ceramah dan postest pembelajaran metode cooperative, metode ceramah lebih efektif digunakan pada penelitian ini, karena metode ceramah memiliki nilai mean yang lebih besar daripada mean pada metode cooperative.

Pengujian statistik menghasilkan signifikansi p sebesar $0,000<0,05$ maka dapat disimpulkan bahwa metode ceramah lebih efektif dibandingkan dengan metode cooperative learning dalam meningkatkan hasil belajar.

\section{Saran}

\section{Bagi Pendidik (Dosen)}

Bagi Pendidik (dosen), hasil penelitian ini untuk dapat dijadikan sebagai pertimbangan dalam memilih metode dan mengembangkan model pembelajaran yang sesuai dengan kondisi tertentu yang dialami oleh mahasiswa, sehingga dapat meningkatkan penguasaan materi pelajaran sesuai dengan tujuan yang diharapkan. Metode ceramah lebih efektif digunakan untuk menyampaikan pembelajaran yang bersifat membaca, dan tau yang membutuhkan analisa yang mendalam, sedangkan metode cooperative lebih efisien digunakan pada penyampaian pembelajaran yang bersifat menulis, mendengarkan, dan berbicara (mengeluarkan pendapat).

2. Bagi Institusi Pendidikan

Bagi Institusi Pendidikan, hasil penelitian ini untuk dapat digunakan sebagai bahan referensi untuk penelitian selanjutnya. dan kiranya untuk peneliti selanjutnya diharapkan dapat melakukan penelitian yang lebih kompleks.

3. Bagi Peneliti

Peneliti mahasiswa keperawatan anestesiologi hasil penelitian ini untuk dapat digunakan sebagai tambahan wawasan tentang metode pembelajaran, dan sebagai masukan untuk menentukan metode pembelajaran untuk diterapkan nantinya. 


\section{Daftar Pustaka}

Dananjaya, Utomo. 2011. Media Pembelajaran Aktif. Bandung : Nuansa.

Hamdani, 2011. Strategi Belajar Mengajar. Bandung : CV Pustaka Setia.

Jacobsen, David A. 2019. Methods For Teaching. Yogyakarta : Pustaka Pelajar.

Jacobs, G.M., Lee, G.S, \& Ball, J. 2016. Learning Cooperative Learning via Cooperative Learning: A Sourcebook of Lesson Plans for Teacher Edu-cation on Cooperative Learning. Singapore: SEAMEO Regional Language Center.

Johnson, DW,\& Johnson,R. 2015. Cooperative and Competion: Theoru and Research. Edina,MN: Interaction Book Company.

Joyce, B., \& Weil, M. 2010. Model of teaching. New Jersey: Prentice-Hall, Inc.

Khoiryah, Atik Hidayat. 2010. Pengaruh Penerapan Metode Active Learning Terhadap Motivasi Belajar siswa dalam Mata Pelajaran Ekonomi. http://www.lib.uinmalang.ac.id/files/thesis/fullchapter/05120054.ps.

Lie, Anita. 2018. “Jigsaw: Cooperative Learning for EFL Student.” Cross

Notoatmodjo, Soekidjo. 2017. Promosi Kesehatan Dan Ilmu Perilaku. Jakarta: Rineka Cipta.

Perkins, D. N., \& Unger, C. 2011. Teaching and learning for understanding. Dalam Reigeluth, C. M. (Ed.): Instructioal-design theories and models: A new paradigm of instruction theory, Volume II. New Jersey: Lawrence Erlboum Associates, Publisher.

Roestiyah, 2018. Belajar Strategi Belajar Mengajar. Jakarta : Rineka Cipta.

Silberman, Melvin L. 2011. Active Learning 101 Cara Belajar Siswa Aktif. Bandung : Nusamedia.

Slavin, Robert E. 2015. Cooperative Learning, Printed in United states of America.

Sudjana, Nana. 2010. Penilaian Hasil Proses Belajar Mengajar. Bandung : PT. Remaja Rosdakarya.

Utami, Dewi Suci. 2010. Pelaksanaan Metode Active Learning Dalam Pembelajaran Fiqih. http:// jurnal. dikti. go.id/ jurnal/ detil/ id/ 19:2799/q/pengarang: \%20Achmad.

Zainul, Asmawi. 2015. Penilaian Hasil Belajar. Jakarta : PAU-PPAI. 